\title{
Gaya Bahasa Tauriyah dalam Ayat al-Qur'an
}

\author{
Yuangga Kurnia Y \\ Universitas Gadjah Mada Yogyakarta \\ yuangga4@gmail.com
}

\begin{abstract}
This paper aimed to research about Badi' style in al-Qur'an's passages. This research used one aspects of Balaghah, tauriyah, and spoke about alQur'an's passages which contains tauriyah style dan the secret behind its using. The objects of this research come from al-Qur'an's passages using style of language/balaghah analysis, especially Ilmu Badi' which concentrated to beauty of meaning (mubassinaat ma'nawiyyah) and importance of understanding tauriyah for another studies focused their object based on al-Qur'an, directly or not. This paper find that there are at least 10 passages which contains tauriyah in al-Qur'an, they are al-Baqarah: 143, al-An'am: 60, at-Taubah: 21, Yunus: 92, Yusuf: 42, Yusuf: 96, Thaha: 5, adz-Dzariyat: 47, ar-Rahman: 6 and al-Ghasiyah: 8. This number of passages erase the old paradigm that recognite only 3 passages in alAn'am: 60, Thaha: 5 and adz-Dzariyat: 47. Understanding tauriyah became important in Tafsir studiy and isthinbatu'l abkaam in Ushu'l Fiqh field, even became one of obligatory requirements for mujtabid.
\end{abstract}

Keywords: Arabic Style, Tauriyah, al-Qur'an's Passages

\begin{abstract}
Abstrak
Penelitian ini bertujuan untuk mengkaji gaya bahasa Badi' yang terdapat dalam ayat-ayat al-Qur'an. Dengan menggunakan satu aspek khusus, yakni tauriyah, penelitian ini berbicara tentang beberapa ayat yang mengandung tauriyah di dalamnya dan rahasia di balik penggunaan gaya bahasa tauriyah. Objek yang diteliti berasal dari ayat-ayat al-Qur'an dan menggunakan analisis stilistika, khususnya Ilmu Badi' yang berfokus pada keindahan makna (mubassinaat ma'nawiyyah) dan pentingnya pemahaman tauriyah bagi disiplin ilmu lain yang berobjek pada al-Qur'an, baik secara langsung atau tidak langsung. Studi ini mengungkapkan sedikitnya ada 10 ayat yang mengandung tauriyah dalam al-Qur'an yaitu pada al-Baqarah: 143, alAn'am: 60, at-Taubah: 21, Yunus: 92, Yusuf: 42, Yusuf: 96, Thaha: 5, adzDzariyat: 47, ar-Rahman: 6 dan al-Ghasiyah: 8. Data tersebut menghapus paradigma lama yang hanya mengakui 3 ayat yang memiliki tauriyah yaitu pada al-An'am: 60, Thaha: 5 dan adz-Dzariyat: 47. Pemahaman tauriyah sendiri diperlukan dalam mengkaji tafsir dan isthinbatu'l abkaam dalam kajian Ushu'l Fiqh, bahkan menjadi salah satu syarat wajib seorang mujtahid.
\end{abstract}

Kata Kunci: Stilistika Arab, Tauriyah, Ayat al-Qur'an 


\section{Pendahuluan}

Kajian stilistika Arab yang memiliki padanan Ilmul Uslub merupakan kajian dalam bahasa Arab yang memperhatikan aspek keindahan atau gaya bahasa. Dalam tradisi linguistik Arab klasik, kajian ini disebut dengan Ilmu Balaghah yang terdiri dari tiga ilmu, yaitu Bayan, Badi' dan Ma'ani. Imu Ma'ani menitikberatkan pada bagaimana kalimat diungkapkan sesuai dengan konteks yang diinginkan. Ilmu Bayan berfokus pada pengungkapan kalimat dengan berbagai gaya bahasa. Adapun ilmu Badi' membahas seputar penyampaian ungkapan dengan cara yang indah, baik secara lafadznya (mubassinat lafdriyyah) maupun secara makna yang terkandung (mubassinat ma'nawiyyah). ${ }^{1}$

Dalam memahami kandungan al-Qur'an perlu menelisik pada kata, kalimat, dan wacana yang dikandungnya. Namun dalam praktiknya, kata dalam al-Qur'an seringkali tidak merujuk pada makna asli atau makna kognitifnya, tetapi merujuk pada makna majasy. Hal tersebut menjadi kesulitan bagi para penggiat ilmu agama untuk menafsirkan dan merumuskan wacana syari'at dari ayat-ayat tersebut. Husein, dalam artikelnya berjudul Ilm Badi' wa Balaghatubu fi Dlaui al-Qur'an al-Karim: Dirasab Balaghiyah Tabliliyah dalam jurnal Dirasat alLughawiyah wa'l Adabiyyah tahun 2013 mencoba membahasnya. Pembahasan tersebut mencakup semua aspek ilm Badi' dalam al-Qur'an. Karena cakupan Ilmu Badi' yang cukup luas dan keterbatasan artikel, penulis hanya membahas beberapa contoh dari tiap gaya bahasa Ilm Badi' yang terdapat dalam al-Qur'an. Dalam artikel ini, penulis ingin mengakumulasi penelitian tersebut dengan berfokus pada gaya bahasa Tauriyah yang merupakan salah satu cakupan Ilmu Badi'.

Tulisan singkat ini mencoba mengupas dua macam keindahan lafadz dan makna yang merupakan objek kajian Ilmu Badi' dengan analisis stilistika. Tauriyah adalah satu dari muhassinat ma'nawiyah yang akan menjadi fokus pada pembahasan ini. Menurut hipotesa penulis, penggunaan gaya bahasa tauriyah dalam al-Qur'an salah satunya untuk memberikan penegasan terhadap ayat tersebut dan memberikan daya tarik yang dapat selalu diingat oleh para pembaca. Hal tersebut diharapkan meninggalkan kesan mendalam bagi pembaca, pendengar, dan penelitinya.

\section{Pengertian Tauriyah}

Tauriyah adalah salah satu bentuk keindahan makna (mubassinat ma'nawiyah) dalam Ilm Balaghah Badi'. Sebagaimana Jinaas, Tauriyah juga memiliki

${ }^{1}$ Ahmad Qasim dan Mahyuddin Dayb, Ulumul Balaghab; al-Badi', al- Bayan wa'l Ma'ani, Tripoli, Lebanon: al-Muassasah al-Haditsah li’l Kitaab, . 2003), h. 50-51. 


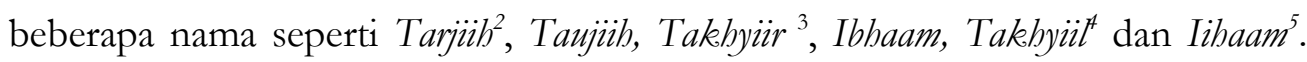
Semua istilah tersebut menunjukkan satu makna yaitu 'tersembunyi' atau 'disembunyikan'.

Adapun definisi Tauriyah tidak mengalami banyak perdebatan dan perbedaan yang mencolok antara bahasawan Arab. Ibn Mu'tazz (2012: 105), 'Atiq (tanpa tahun: 122), Ahmad Qasim (2003: 76), al-Jaly (1992: 135), Badruddin Ibn Malik (1989: 260), al-Madany (1969: 5) dan al-Hasyimi (1999: 300) sepakat bahwa Tauriyah adalah ketika pembicara atau penulis mengutarakan sebuah lafadz mufrad yang memiliki dua makna, yaitu makna yang dekat (ي (قريب) dan makna yang jauh (معنى بعيد). Makna yang dekat memiliki beberapa petunjuk (qarinah) sehingga dirasa jelas (dhabir) sebagai makna yang dimaksud oleh si pembicara atau penulis, namun makna yang dimaksud adalah makna yang jauh dan samar-samar. Meskipun beberapa penulis memiliki redaksi masingmasing, namun tidak ada yang keluar dari definisi tersebut. Selain penulis-penulis di atas, beberapa bahasawan lain seperti Taqiyuddin Ibn Hujjah al-Hamwy, Shalahuddin ash-Shafady, Khatib Quzwainy dan Zakiyuddin Abi'l Asbu' menyutujui definisi di atas. ${ }^{6}$

Contoh dari Tauriyah terdapat dalam ayat

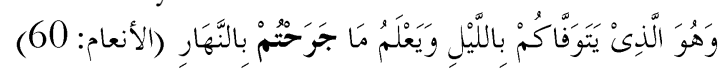

kata "جرحتم" memiliki makna dekat 'luka' dan makna jauh 'berbuat dosa'. Makna dekat dari kata tersebut terasa jelas dan dirasa sebagai makna yang dimaksud

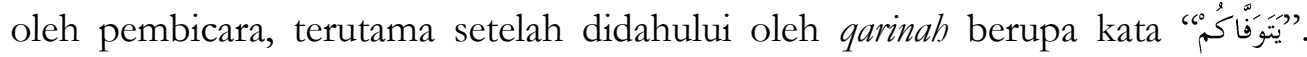
Namun makna yang diinginkan pembicara makna jauh, yaitu 'berbuat dosa'.

2Badruddin Ibn Malik, Al-Mishbaah fi'l Ma'ani, Badi' wa'l Bayan, (Kairo: Maktabah alAdab, 1989), h. 260.

${ }^{3}$ Abdul Aziz Atiq, Ilmu'l Badi, (Beirut: Daaru'n Nahdhah al-'Arabiyyah, Tanpa Tahun), h. 122 .

4 'Ali Shadruddin Ibn Ma'shum Al-Madany, Anwaaru'r Rabii' fi Anwaa'il Badi', Juz 5, (Najaf: Mathba'atu Na'maan, 1969), h. 5.

5Shafiyuddin Al-Jaly, 1992. Syarbu'l Kafiyah al-Badi'iyyah fi Uluumi'l Balaghab wa Mabaasini'l Lafdzi, (Beirut: Daar Shadir, 1992), h. 135.

${ }^{6}$ Abdul Aziz Atiq, Ilmu'l Badi, h. 122.

${ }^{7}$ Sayyid Ahmad Al-Hasyimi, Jawahiru'l Balaghah fi'l Ma'ani, Bayan wa'l Badi', (Beirut: alMaktabah al-'Ashriyyah, 1999), h. 301 


\section{Pembagian Tauriyah}

Sebagaimana para bahasawan sepakat dalam mendefinisikan Tauriyah, mereka juga terlihat satu pendapat dalam pembagian Tauriyah. Ibn Mu'tazz ${ }^{8}$, 'Atiq ${ }^{9}$, Qasim (2003: 77), Malik ${ }^{10}$ dan al-Hasyimi ${ }^{11}$ membagi Tauriyah ke dalam 4 macam, yaitu:

a. Tauriyah Mujarradah, yaitu kalimat yang di dalamnya tidak terdapat qarinah, baik yang merujuk pada makna yang dekat maupun makna yang jauh. Salah satu ayat al-Qur'an yan mengandung contoh ini adalah

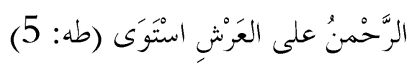

Kata "استوى" memiliki makna dekat 'duduk' dan makna jauh 'memiliki/menguasai' (الاستيلاء والملك).

b. Tauriyah Murasysyahah, yaitu ungkapan atau kalimat yang di dalamnya terdapat qarinah yang merujuk kepada makna yang dekat. Ungkapan ini semakin menegaskan kecondongan maksud pembicara kepada makna yang dekat. Ayat al-Qur'an yang memiliki Tauriyab ini adalah

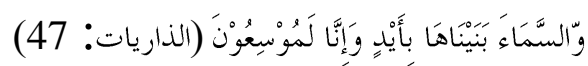

Kata “أيد" memiliki makna dekat 'tangan' dan diperkuat dengan adanya qarinah "بنيناهl” yang merupakan pekerjaan yang dilakukan dengan tangan. Namun makna yang dimaksud oleh pembicara (dalam konteks ini adalah Allah SWT) adalah makna jauhnya 'kuasa'. Dalam macam ini, qarinah bagi makna yang dekat dapat disebutkan sebelum lafadz yang mengandung Tauriyah ataupun setelahnya.

c. Tauriyah Mubayyanah, yaitu kalimat yang di dalamnya terdapat qarinah yang merujuk pada makna yang jauh, baik muncul sebelum lafadz yang mengandung Tauriyah ataupun setelahnya. Contohnya adalah

$$
\text { أرى ذنب السرحان في الأفق طالعا \# فهل منكن أن الغزالة تطلع؟ }
$$

kata "'دنب السرحان" memiliki makna dekat 'ekor binatang'. Adapun makna jauh dari kata tersebut adalah 'cahaya mentari di pagi/siang hari' dan diperkuat dengan qarinah "طالعا" Lلغزالة" Lafadz lainnya adalah" memiliki makna dekat 'rusa' dan makna jauh 'matahari'. Kehadiran makna jauh semakin

8 Abu Abbas Abdullah Ibn Mu'tazz, Kitaabu'l Badi', (Beirut: Muassasah al-Kutub atsTsaqafiyah, 2012), h. 106.

${ }^{9}$ Abdul Aziz Atiq, Ilmu'l Badi, h. 126.

${ }^{10}$ Badruddin Ibn Malik, Al-Mishbaah fi'l Ma'ani, Badi' wa'l Bayan, h. 262.

${ }^{11}$ Sayyid Ahmad Al-Hasyimi, Jawabiru'l Balaghah fi'l Ma'ani, Bayan wa'l Badi', h. 300. 
terasa dengan adanya qarinah "تطلع" setelah lafadz yang mengandung tauriyah tersebut. $^{12}$

d. Tauriyah Muhayya'ah, yaitu kalimat/ungkapan yang di dalamnya terdapat dua kata yang mengandung Tauriyah. Namun kata tersebut tidak dapat dipahami sebagai tauriyah bila tidak terdapat kata lain yang berfungsi sebagai qarinah bagi salah satu atau keduanya. Contohnya terdapat dalam ungkapan berikut:

$$
\text { وأظهرت فينا من سميك سنة \# \# فأظهرت ذاك الفرض من ذلك الندب }
$$

kata "الفرض" memiliki makna dekat 'sunnah dan wajib berdasarkan hukum syari'at Islam'. Kata yang menunjukkan adanya Tauriyah pada kedua kata tersebut adalah "سنة". Adapun makna jauh yang dimaksudkan oleh pembicara (dalam konteks ini Ibn Sina) adalah 'pemberian' dan 'orang yang cepat memenuhi berbagai keinginan dan hajat'. Kata yang berfungsi sebagai qarinah ini dapat terletak sebelum kata yang mengandung Tauriyah maupun sesudahnya ${ }^{13}$.

Tauriyah merupakan salah satu keindahan makna yang memerlukan ketelitian penya'ir atau pembicara dalam memilih kata yang mengandung tauriyah dan kekayaan khazanah keilmuan bahasanya. Hal ini yang membuat tauriyah menjadi sebuah seni keindahan berbahasa tingkat tinggi yang hanya dapat dilakukakan oleh pujangga yang benar-benar ahli di bidangnya. Karena tingginya rasa keindahan yang ditimbulkan, para pujangga abab VI, VII dan VIII H berlomba-lomba dalam menggunakan tauriyah dalam karya sastra mereka, baik prosa maupun puisi atau sya'ir. Menurut sejarah, al-Qadhi al-Faadlil (w.596 H) merupakan orang pertama yang memperkenalkan istilah ini dan menyeru kepada para pujangga di zamannya untuk memperbanyak penggunaannya dalam karyakarya mereka. Namun pendapat lain mengatakan bahwa gubahan pertama yang menggunakan tauriyah adalah gubahan-gubahan al-Mutanabby yang kemudian disebarluarkan oleh al-Qadhi al-Faadlil. ${ }^{14}$

\section{Tauriyah dalam Ayat al-Qur'an}

al-Qur'an merupakan salah satu mukjizat yang dapat bertahan abadi hingga akhir zaman. Ia diwahyukan kepada Nabi Muhammad SAW yang buta huruf selama 23 tahun dan menghasilkan karya sastra yang luar biasa. Karyakarya pujangga Arab yang dahulu dibangga-banggakan seketika tunduk dan

12 Abdul Aziz Atiq, Ilmu'l Badi, h. 129.

13 Abu Abbas Abdullah Ibn Mu'tazz, Kitaabu'l Badi', h. 106 - 107, Abdul Aziz Atiq, Ilmu'l Badi,126 -132, Sayyid Ahmad Al-Hasyimi, Jawabiru'l Balaghah fi'l Ma'ani, Bayan wa'l Badi', 300 dan Badruddin Ibn Malik, Al-Mishbaah fi'l Ma'ani, Badi' wa'l Bayan, h. 260 -262.

${ }^{14}$ Abdul Aziz Atiq, Ilmu'l Badi, h. 132 - 133 
mengakui keindahan gaya bahasa al-Qur'an dan kekuatan makna yang terkandung di dalamnya. Sebagaimana arti kata mukjizat adalah 'sesuatu yang melemahkan orang lain untuk menghasilkan hal yang serupa', maka al-Qur'an berhasil membungkam kesombongan pujangga Arab yang bangga akan karya sastra mereka.

Keindahan gaya bahasa al-Qur'an terdiri dari lafadz-lafadznya yang indah dan kekuatan makna-makna yang dikandungnya. Tak ayal para bahasawan dan sastrawan Arab banyak yang meneliti dan mendalami berbagai rahasia di balik kesempurnaan al-Qur'an. Hal tersebut selain untuk menambah keilmuan dalam bidang bahasa, juga berimplikasi kuat pada bidang keilmuan lainnya yang menjadikan al-Qur'an sebagai objek kajian maupun pijakan seperti tafsir, ulumul Qur'an, figh dan ushul fiqh. Melihat pentingnya pemahaman al-Qur'an dengan medium Bahasa Arab membuat banyak ilmuwan menyusun buku yang berisi pemahaman makna-makna al-Qur'an dari segi sintaksis dan stilistikanya. Tulisan singkat ini mencoba berbicara tentang gaya bahasa tauriyah yang merupakan salah satu kajian dalam Ilm Balaghah Badi' pada beberapa ayat al-Qur'an. Ayatayat yang akan dibahas adalah al-Baqarah: 143, al-An'am: 60, at-Taubah: 21, Yunus: 92, Yusuf: 42, Yusuf: 96, Thaha: 5, adz-Dzariyat: 47, ar-Rahman: 6 dan al-Ghasiyah: 8.

Pada contoh di atas telah dipaparkan 3 ayat al-Qur'an yang mengandung tauriyah, yaitu al-An'am: 60, Thaha: 5 dan adz-Dzariyat: 47. Pada ayat pertama yang berbunyi:

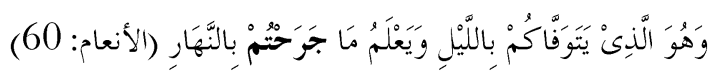

Kata "جرحتم" memiliki makna dekat 'luka' dan makna jauh 'berbuat dosa'. Makna dekat terasa lebih tepat menggambarkan maksud pembicara ketika didahului kata "يتوفاكم". Namun maksud dari kata tersebut adalah makna jauh 'berbuat dosa' (ارتكاب الذنوب). Ayat tersebut merupakan ayat yang paling sering muncul sebagai contoh dari bab tauriyah. ${ }^{15}$

Ayat kedua adalah Thaha: 5 yang berbunyi:

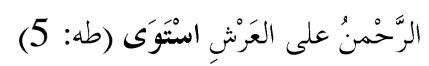

Kata "استوى" memiliki makna dekat 'duduk' dan makna jauh 'memiliki/menguasai' (الاستيلاءوالملك). Dalam ayat ini tidak terdapat qarinah yang merujuk kepada salah satu makna, baik makna dekat maupun makna jauh,

\footnotetext{
${ }^{15}$ Sayyid Ahmad Al-Hasyimi, Jawabiru'l Balaghah fi'l Ma'ani, Bayan wa'l Badi', h. 301 lihat juga Abdul Aziz Atiq, Ilmu'l Badi, h. 125
} 
sehingga para bahasawan menggolongkannya ke dalam tauriyah mujarrada ${ }^{16}$. Bentuk tauriyah yang sama juga dapat ditemukan pada ar-Ra'ad: 2 yang berbunyi:

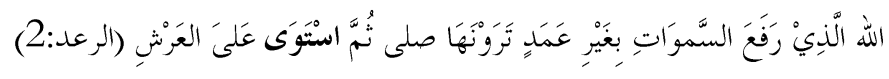
berbunyi:

Hal tersebut berbeda dengan ayat ketiga yaitu adz-Dzariyat: 47 yang

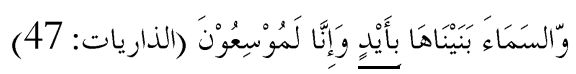

Kata “'ئيد" memiliki makna dekat 'tangan' dan diperkuat dengan adanya qarinah "بنيناهl" yang merupakan salah satu pekerjaan yang amat berkaitan dengan 'tangan'. Namun makna jauh 'kuasa' lah yang dimaksudkan oleh pembicara dalam ayat tersebut. Dengan adanya qarinah tersebut, ayat ini termasuk contoh dari tauriyah murasysyabah. ${ }^{17}$

Ayat keempat hingga kesepuluh merupakan ayat-ayat yang juga mengandung tauriyah namun jarang muncul di bab-bab tauriyah dalam buku-buku Ilmu Badi. Beberapa disadur dari buku Badi'ul Qur'an karya Ibn Abi'l Ishba', artikel Nashruddin Ibrahim Ahmad Husein dalam jurnal Dirasat al-Lughawiyah عa'l Adabiyyah IIUM edisi Desember 2013 yang berjudul “ " علم البديع وبلاغته في ضوء القرآن الكريع: دراسة بلاغية dan forum tanya-jawab online di situs http://newx.7olm. org/ t166-topic pada 16-17 Oktober 2013. berbunyi:

Ayat keempat yang mengandung tauriyah adalah al-Baqarah: 143 yang

$$
\text { وَكَذِلِكَ جَعَلْنَاكُمْ أُمَّة وَسَطًَا (البقرة: 143) }
$$

Kata “وسطا" memiliki makna dekat 'pertengahan' atau 'yang memiliki kiblat di antara kiblat orang Yahudi dan Nasrani' sebagaimana yang tertulis dalam ayat 145 bahwa kaum Yahudi menghadap ke barat bukit Tursina dan kaum Nasrani yang menghadap ke Timur:

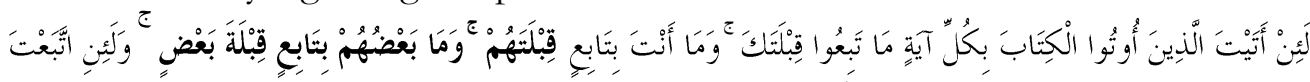

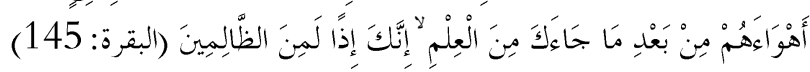

h. 77

${ }^{16}$ Ahmad Qasim dan Mahyuddin Dayb, Uluumu'l Balaghab; al-Badi', al- Bayan wa'l Ma'ani, ${ }^{17}$ Ibid, h. 77 
Adapun makna jauh yang dimaksud oleh Allah SWT adalah 'pilihan'. Ditinjau dari pembagian tauriyah di atas, ayat ini juga termasuk ke dalam tauriyah murasysyahab. ${ }^{18}$

Ayat selanjutnya adalah at-Taubah: 21 yang berbunyi:

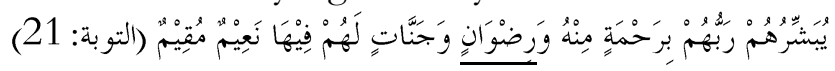

Kata "رضوان" memiliki makna dekat 'malaikat penjaga surga' dengan adanya qarinah yang datang sesudahnya berupa kata "جنات", sehingga banyak pembaca memahami bahwa maksud kata " “وضوانو" adalah makna dekatnya. Adapun makna yang dimaksud oleh Allah SWT adalah makna jauhnya 'keridhaan Allah' yang merujuk pada qarinah yang muncul sebelumnya yaitu “رمة"

Ayat keenam adalah Yunus: 92 yang bercerita tentang tenggelamnya Fir'aun dan bala tentaranya di Laur Merah. Allah SWT berfirman:

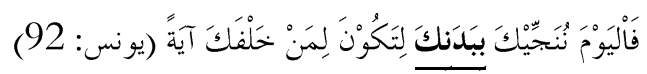

kata "بدن" dipahami memiliki makna dekat 'perisai' atau 'baju zirah' melihat konteks keadaan saat itu dimana bala tentara Fir'aun mengenakan pakaian zirah lengkap dengan perisai dan persenjataan dalam pengejaran Musa as dan Bani Israil. Namun maksud dari ayat ini adalah makna jauhnya yaitu 'tubuh' atau 'tubuh sebenarnya' dari tubuh Fir'aun yang dimaksudkan sebagai tanda kebesaranNya dan peringatan bagi mereka yang merasa sombong dan pongah sebagaimana sifat yang ditunjukkan oleh Fir'aun. ${ }^{19}$ Pemahaman makna jauh ini juga seolah menjawab pendapat yang mengatakan bahwa Fir'aun dapat selamat dari azab tersebut berkat bantuan baju zirahnya.

Surah Yusuf memiliki dua ayat yang mengandung tauriyah. Ayat pertama adalah:

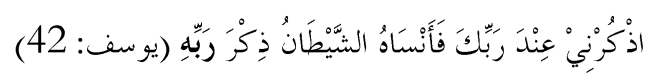

Kata "بر" memiliki dua makna, dekat dan jauh. Makna dekatnya adalah 'Tuhan' dengan adanya penyebutan "نشيطان" yang lekat dengan makhluk yang mengganggu manusia untuk lupa akan 'Tuhan'nya. Makna jauh yang dimaksud oleh perkataan Nabi Yusuf as adalah 'tuannya' atau 'rajanya' sebagaimana bermakna sama dengan “ربك" yang disebutkan terlebih dahulu.

\footnotetext{
${ }^{18}$ Ibnu Aby Ishba', Badii'ul Qur'an, (Kairo: Nahdhatul Mishry, 2008), h. 103

${ }^{19} \mathrm{Ibid}$, h. 102.
} 
Ayat kedua yang muncul di surat Yusuf adalah ketika Nabi Ya'qub as merasa adanya kehadiran Nabi Yusuf as yang telah lama "dianggap" meninggal, anak-anaknya berkata:

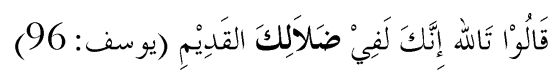

Kata “ضَ" memiliki makna dekat 'kesesatan' karena masih mengharap kehadiran Nabi Yusuf as setelah meninggal selama lebih dari 30 tahun dan 'kesesatan' karena masih saja bergelimang kesedihan semenjak ditinggal Nabi Yusuf as dalam waktu yang lama. Adapun makna jauh yang dimaksud oleh anakanak Nabi Ya'qub as adalah 'kecintaan'nya yang terlampau sangat terhadap Nabi Yusuf as dan Bunyamin dibanding saudara-saudara lainnya. ${ }^{20}$ Pendapat lain mengatakan bahwa makna jauh yang dimaksud adalah 'kesesatan' Nabi Ya'qub as yang mengutamakan Nabi Yusuf as dan Bunyamin dibanding anak-anak lainnya, sebagaimana disiratkan pada ayat 8 di surah yang sama: ${ }^{21}$

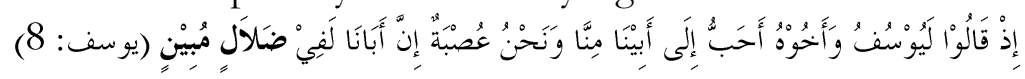

Selanjutnya, salah satu ayat dalam surah ar-Rahman: 6 yang berbunyi:

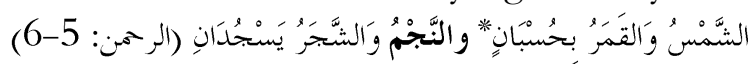

Kata "النجم" memiliki makna dekat 'bintang' sebagaimana lanjutan dari ayat sebelumnya yang menyebutkan "الشمس" 'matahari' dan “"القمر" 'bulan' yang ketiganya termasuk ke dalam satu bidang semantik (semantic field) yaitu bendabenda angkasa. Namun ayat tersebut akan terasa berbeda setelah datangnya kata " الشجرر" 'pepohonan' setelah kata yang mengandung tauriyah tersebut. Karenanya, dapat dipahami bahwa makna yang dimaksud adalah makna jauh 'jenis tumbuhan' atau dikenal pula dengan 'aster'. ${ }^{22}$

Ayat terakhir adalah al-Ghasiyah: 8 yang berbunyi:

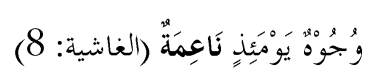

Kata "ناعِمة" memiliki makna dekat 'lembut'. Ayat yang didahului tentang ayat yang menjelaskan dahsyatnya siksa di neraka, sehingga beberapa pembaca memahami bahwa makna dari kata tersebut adalah 'lemah lembut'. Adapun yang dimaksud oleh ayat tersebut adalah 'penuh dengan kenikmatan dan kemuliaan'

${ }^{20} \mathrm{Ibid}$, h. 102.

${ }^{21}$ Nashruddin Ibrahim Ahmad Husein, Ilm Badi' wa Balaghatubu fi Dlaui al-Qur'an alKarim: Dirasah Balaghiyah Tabliliyah dalam jurnal Dirasat al-Lughawiyah wa'l Adabiyyah (Malaysia: IIUM, 2013), h. 131.

${ }^{22}$ Nashruddin Ibrahim Ahmad Husein, Ilm Badi' wa Balaghatubu fi Dlaui al-Qur'an alKarim: Dirasah Balagbiyah Tabliliyah, h. 131. 
(وجوه في نعمة وكرامة yang merupakan makna jauh dari kata tersebut. Maksud pembicara yang mengacu pada makna jauh dapat dipahami dari ayat-ayat setelahnya yang menerangkan secara detail bentuk-bentuk kenikmatan dan kemuliaan yang diterima oleh para penghuni surga.

\section{Rahasia Keindahan Tauriyah}

Tauriyah merupakan salah satu muhassinaat badi'iyyah di samping jinaas, saja' dan thibaaq. Dua hal yang menjadi keunggulan mubassinaat badi'iyyah adalah mufajaah (faktor kejutan) dan Imtaa' (faktor hiburan/keindahan) yang keduanya menyasar langsung pada 'rasa' (Syu'ur) pendengar dan pembaca. Hal ini juga merupakan salah satu tujuan penggunaan gaya bahasa dan stilistika dalam Bahasa Arab, yaitu memanfaatkan serta memaksimalkan potensi yang dimiliki tiap lafadz (likulli lafdzatin hayawiyatuhaa). Potensi inilah yang digunakan untuk memberikan faktor kejutan kepada pendengar dan memberikan kesan yang mendalam di hati dan pikiran pendengar. Yang menjadi sasaran stilistika, khususnya muhassinaat badi'iyyah adalah memberikan kesan yang mendalam dari perasaan ('atifah) untuk sampai kepada rasio (fikrah) dan membangkitkan rasa (syu'ur) atau itsaaratu'l 'aatifah ila'l fikerah wa ïqaadzu'sy syu'ur.

Adanya kolaborasi yang seimbang antara makna dekat (ma'na qariib) dan makna jauh (ma'na baïd) juga menjadi salah satu kekuatan dan kekhasan tauriyah dalam memainkan rasio dan rasa pendengar. Hal ini memberikan kesan yang mendalam dan tak mudah terlupa oleh pendengar atau pembaca al-Qur'an meski tidak mendengarkan langsung dari sang pembicara (Allah). Gaya bahasa ini juga merupakan bentuk paling halus dan lembut (lathif) dari Pembicara kepada pendengar dan pembaca dengan menyembunyikan makna yang dimaksudkannya. ${ }^{23}$ Alih-alih menegur langsung, Pembicara menggunakan gaya bahasa ini dengan menyamarkan maksud perkataan antara dua makna, yang satu dekat dan jelas dan lainnya jauh dan samar-samar. Hal ini membuat mereka yang paham benar alur pembicaraan (konteks/siyaaq) akan dapat memahami maksud si Pembicara meski tersamarkan.

Ahmad Qasim menambahkan bahwa penyamaran maksud pembicara ini merupakan salah satu gaya bahasa yang disenangi (mustahbab) dalam penggunaan gaya bahasa syi'ir dan seni lainnya. Hal tersebut menjadi nilai tambah karena menguji dan menyasar langsung kepada tingkat intelegensi mitra tutur dan rasionya. Semakin tinggi rasio dan rasa pendengar akan segera menafikan makna dekat dari perkataan yang diterimanya dan makna dekat dianggap kurang efektif dan kurang memberikan efek yang signifikan kepada pendengar. Tauriyah juga

${ }^{23}$ Ibnu Aby Ishba', Badii'ul Qur'an, h. 103. 
melazimkan adanya kontemplasi (ta'ammul) pendengar dan pembaca atas apa yang disampaikan pembicara. Kontemplasi inilah yang menjadi kunci penafsiran yang beragam dan berbeda dari setiap pendengar atau pembicaranya. ${ }^{24}$

Kekuatan tauriyah dalam pemilihan kata dan lafadz yang memiliki makna dekat dan makna jauh di dalamnya juga merupakan salah satu bentuk kejutan yang mengejutkan akal dan nurani (drihn) pembacanya. Kejutan ini yang secara tidak langsung meminta perhatian lebih dari pendengar terhadap apa yang disampaikan pembicara, karena dalam melafalkan kalaam tidak cukup hanya mengutamakan rasio (I'maalu'l Fikrah) tanpa dibarengi dengan kehadiran perasaan dan nurani di sana. Keutamaan tauriyah inilah yang membuat banyak bahasawan Arab menganggapnya sebagai bentuk uslub yang paling bijaksana atau uslub dari Yang Maha Bijaksana ${ }^{25}$ dan bukti lain dari tingginya tataran semantis dan gaya bahasa yang digunakan dalam al-Qur'an ${ }^{26}$.

\section{Landasan Aksiologi Tauriyah bagi Disiplin Ilmu Lain}

Sepuluh ayat di atas yang mengandung tauriyah hanya beberapa ayat yang mampu dideteksi di antara ribuan ayat lainnya. Selain ayat-ayat tersebut, masih banyak tersebar ayat-ayat lain yang mengandung tauriyah atau kajian-kajian lain dalam Ilm Balaghah dalam memahami maksud dan gaya bahasa yang digunakan.

Memahami adanya ayat yang mengandung tauriyah menjadi penting dan fundamental bagi seluruh muslim yang ingin memahami al-Qur'an lebih lanjut. Proses penerjemahan al-Qur'an ke berbagai bahasa, salah satunya Indonesia, membutuhkan pemahaman yang benar terkait keseluruhan gaya bahasa yang digunakan di dalam al-Qur'an di samping kemampuan akan penguasaan Bahasa Arab yang mumpuni. Hal ini bermanfaat untuk memindahkan ide dan konsep (فكرة) yang ingin disampaikan pembicara dalam Bahasa Arab ke Bahasa Indonesia dengan latar belakang budaya yang berbeda satu sama lain.

Selain dalam ranah penerjemahan, pemahaman akan gaya bahasa alQur'an, khususnya tauriyah diperlukan dalam ilmu-ilmu yang menjadikan ayat alQur'an sebagai objek kajian seperti tafsir dan ushu'l fiqh. Dalam tafsir al-Qur'an, kata "أيد" dan " termasuk dalam ayat-ayat mutasyabihaat. Ayat-ayat Ma'ani, h. 82.

${ }^{24}$ Ahmad Qasim dan Mahyuddin Dayb, Uluumu'l Balaghab; al-Badi, al- Bayan wa'l

${ }^{25}$ Dahiilu'llah Ibn Muhammad Ash-Shahafy, Al-Badi' fi'l Qur'an 'inda'l mutaakbhirin wa atsarubu fid'diraasat al-balaghiyah. Tesis Universitas Ummu'l Qura Fakultas Bahasa Arab konsentrasi Balaghah, (Mekkah: Ummu'l Qura, 1990), h. 290.

${ }^{26}$ Nashruddin Ibrahim Ahmad Husein, Ilm Badi' wa Balaghatubu fi Dlaui al-Qur'an alKarim: Dirasab Balaghiyah Tabliliyah, h. 131. 
mustasyabihaat sendiri adalah ayat-ayat yang maksud di dalamnya tidak dapat diketahui secara langsung dan pasti tanpa proses ta'wiil. Proses ta'wiil pun masih menjadi perbincangan hangat antara pro dan kontra di kalangan ulama tafsir salaf dan khalaf. ${ }^{27}$ Tanpa pemahaman akan Ilmu Balaghah Badi, khususnya tauriyah, lebih sulit kiranya memahami gaya bahasa dan maksud yang diinginkan oleh pembicara.

Hal senada juga terjadi dalam kaidah Isthinbatu'l abkaam dalam Ushul Fiqh. Ayat-ayat yang mengandung satu lafadz yang memiliki banyak makna disebut dengan "al-Musytarak". Lawan dari al-Musytarak adalah al-Muraadif, yaitu beberapa lafadz yang memiliki kesamaan makna atau sinonimi. Dalam almusytarak terdapat banyak makna yang dimaksud oleh lafadz tersebut, baik yang haqiqy maupun yang majasy. ${ }^{28}$ Untuk dapat mengetahui makna mana yang diinginkan oleh si pembicara, ahli ushul harus memahami penggunaan tauriyah dan gaya bahasa lainnya dalam ayat tersebut. Hal tersebut semata-mata untuk meminimalisir kesalahan penafsiran dan pengambilan hukum atau kaidah ushuliyyah yang terkandung di dalamnya.

Karena pentingnya pemahaman akan gaya bahasa dan tidak cukup hanya bermodal ketrampilan dasar berbahasa Arab seperti sintaksis dan morfologis untuk memahami maksud dari ayat-ayat al-Qur'an dan hadits, para ulama sepakat bahwa penguasaan Bahasa Arab yang lebih luas dan mendalam sangat penting. Lebih lanjut, penguasaan bahasa tersebut meliputi aspek semantis, sintaksis, morfologis, stilistika dan kosa kata. ${ }^{29}$ Syarat ini menjadi wajib bagi setiap muslim yang ingin berijtihad dalam hukum-hukum Islam atau menjadi mujtahid.

Namun di samping tauriyah, masih banyak gaya bahasa yang perlu dipahami oleh para pelajar dan mujtahid. Semuanya dalam rangka berusaha memahami kalamNya dan maksudNya dan mengaplikasikannya ke dalam kehidupan sehari-hari. Tauriyah adalah salah satu usaha dan ijtihad bahasawan dalam memahami ayat-ayatNya, baik yang tersurat dalam kitab suciNya maupun yang tersirat.

\footnotetext{
${ }^{27}$ Khalid Abdurrahman Al-'Ak, Ushuulu't Tafsiir wa Qawa'idubu. Damaskus: Daar anNafaais, 1986), h. 44-45.

28 Syamsuddin Muhammad Ibn Muflih al-Muqaddasi Al-Hanbaly, Ushuul'ul Figh, (Riyadh: Maktabatu'l 'Abiikaan, 1999), h. 60.

${ }^{29}$ Abdul Aziz Al-Khiyath, Syuruuthu'l Ijtihaad, (Kairo: Daaru's Salaam li'th Thiba'ah wa an-Nasyr wa't Tauzi', 1986), h. 30
} 


\section{Kesimpulan}

Ilmu Balaghah Badi' merupakan kajian Ilm Balaghah yang berbicara tentang keindahan, baik dalam ranah lafadz (mubassinaat lafdriyab) maupun ranah makna (mubassinaat ma'nawiyyah). Tauriyah merupakan satu dari banyak mubassinaat ma'nawiyyah yang terkandung dalam karya sastra Arab yang paling tinggi dan juga mu'jizat Nabi terakhir yang beratahan hingga akhir zaman, alQur'an. Sebagaimana muhassinaat lafdriyah yang condong kepada musikalitas dalam pemilihan diksi dan kata, mubassinaat ma'nawiyyah condong kepada pemilihan makna yang memanjakan akal dan imajinasi para pembaca atau pendengar.

Beberapa ayat yang mengandung tauriyah di atas merupakan bukti keindahan pemilihan kata dan diksi yang memiliki makna yang dalam, sehingga mampu memberikan kesan di sanubari pembaca dan pendengarnya. Hal ini juga semakin menguatkan pendapat akan kekayaan kosa kata Arab dan tingginya kesusteraan Arab, baik pada masa pra-Islam hingga datangnya Islam.

Tidak berhenti di sini saja, berbagai rahasia keindahan gaya bahasa Arab penting kiranya untuk dipahami dan dikuasai bagi para penuntut ilmu yang menjadikan ayat al-Qur'an sebagai objek kajiannya. Lebih jauh, salah satu syarat mutlak menjadi seorang mujtahid, baik ahli tafsir, ahli fiqh maupun ahli ushul, adalah menguasai Bahasa Arab dari berbagai tataran linguistik (fonologi, morfologi, sintaksis, dan semantik) hingga stilistika Arab. Semuanya demi mencapai pemaknaan yang tepat sasaran dan pemahaman yang baik akan maksud-maksudNya dalam kalamNya, baik yang tersurat maupun yang tersirat. 


\section{Daftar Pustaka}

'Atiq, Abdul Aziz. Ilmu'l Badi'. Beirut: Daaru'n Nahdhah al-'Arabiyyah, Tanpa Tahun

Al-'Ak, Khalid Abdurrahman. Ushuulu't Tafsiir wa Qawa'idubu. Damaskus: Daar an-Nafaais, 1986

Al-Hasyimi, Sayyid Ahmad. Jawahiru'l Balaghah fi'l Ma'ani, Bayan wa'l Badi'. Beirut: al-Maktabah al-'Ashriyyah, 1999

Al-Hanbaly, Syamsuddin Muhammad Ibn Muflih al-Muqaddasi. Ushuul'ul Fiqh. Riyadh: Maktabatu'l 'Abiikaan, 1999

Al-Jaly, Shafiyuddin. Syarbu'l Kafiyah al-Badi'iyyah fi Uluumi'l Balaghah wa Mahaasini'l Lafdri. Beirut: Daar Shadir, 1992

Al-Khiyath, Abdul Aziz. Syuruuthu'l Ijtibaad. Kairo: Daaru's Salaam li'th Thiba'ah wa an-Nasyr wa't Tauzi', 1986

Al-Madany, 'Ali Shadruddin Ibn Ma'shum. Anwaaru'r Rabii' fi Anwaa'il Badi', Juz 5. Najaf: Mathba'atu Na'maan, 1969

Ash-Shahafy, Dahiilu'llah Ibn Muhammad. Al-Badi' fi'l Qur'an 'inda'l mutaakbhirin wa atsarubu fid'diraasat al-balaghiyah. Tesis Universitas Ummu'l Qura Fakultas Bahasa Arab konsentrasi Balaghah, 1990

Husein, Nashruddin Ibrahim Ahmad. "Ilm Badi' wa Balaghatuhu fi Dlaui alQur'an al-Karim: Dirasah Balaghiyah Tahliliyah". Jurnal Dirasat alLughawiyah wa'l Adabiyyah IIUM: Desember 2013

Ishba', Ibnu Aby. Badii'ul Qur'an. Kairo: Nahdhatu'l Mishry, 2008

Malik, Badruddin Ibn. Al-Mishbaah fi'l Ma'ani, Badi' wa'l Bayan. Kairo: Maktabah al-Adab, 1989

Mu'tazz, Abu Abbas Abdullah Ibn. Kitaabu'l Badi'. Beirut: Muassasah al-Kutub ats-Tsaqafiyah, 2012

Qasim, Ahmad dan Mahyuddin Dayb. Uluumu'l Balaghab; al-Badi', al- Bayan wa'l Ma'ani. Tripoli, Lebanon: al-Muassasah al-Haditsah li'l Kitaab, 2003

http://newx.7olm.org/t166-topic diakses pada Sept 13, 2017, 5:45 wib 